\title{
Chapter 8 \\ Magnitude and Extent of Water \\ Clarification Services Provided by Bivalve Suspension Feeding
}

\author{
Peter J. Cranford
}

\begin{abstract}
Studies in bivalve ecology have emphasized that phytoplankton dynamics in coastal regions may be strongly coupled with bivalve suspension feeding activity to the extent that the bivalves play a major ecological role in controlling phytoplankton biomass. The water clarification capacity of natural and cultured bivalve populations serves as the foundation for what is considered to be a manageable bioengineering tool for mitigating the major symptoms of eutrophication and thereby providing positive ecosystem-scale services. Although often predicted, suspended particle depletion by bivalve aggregations has only recently been measured directly. Field observations of food depletion by bivalve aggregations confirm the large capacity for water clarification. However, progressively increasing the standing stock of bivalves to achieve greater water clarification benefits eventually lead to inefficiencies in bivalve feeding related to increased flow reduction from structure drag, which facilitates an increase in water re-filtration. These physical and biological processes ultimately constrain the maximum water clarification capacity of the population to levels that can be substantially less than previously predicted. Positive ecosystem services from bivalve grazing are likely to occur in many coastal areas experiencing eutrophication (e.g. Lindahl 2011). However, it is important to take an ecosystem-based management approach that also considers the potential for adverse environmental interactions that may be associated with intensive and extensive suspended bivalve operations.
\end{abstract}

\begin{abstract}
Chinese 摘要:双壳贝类的生态学研究表明, 沿海地区的浮游植物 种群动力学过程与滤食性双壳贝类的摄食活动密切相关, 双壳贝类在调控浮 游植物生物量方面有着重要的生态作用。野生和养殖的双壳贝类种群的滤食 作用能够减轻水域富营养化, 从而提供了积极的生态系统水平的服务功能。 尽管在之前有过许多理论预测,但是直到最近我们才可以直接测量双壳贝类 对水体中悬浮颗粒物的滤食量。在养殖水域的观测结果表明双壳贝类通过 滤食而净化的水体相当可观。然而,双壳贝类的净水能力与养殖量并非线性 关系,过量的贝类养殖会导致养殖双壳贝类净水能力下降,其中一个主要原因
\end{abstract}

\footnotetext{
P. J. Cranford ( $\square)$

St. Andrews Biological Station, St. Andrews, NB, Canada

e-mail: Peter.Cranford@dfo-mpo.gc.ca
} 
是大规模的养殖设施会对水流产生阻碍作用,从而导致贝类对海水进行重复 过滤。这些流体动力学以及生物过程会制约双壳贝类种群的最大净水效率, 使之大大低于预期水平。养殖双壳贝类提供的生态系统服务功能对许多富营 养化水域有着积极的控制效果(如Lindahl2011)。尽管基于生态系统水平的管 理方法可以较好的进行双壳贝类养殖规划,但是我们仍然需要考虑高密度养 殖对环境带来的其他方面的负面影响。.

Keywords Bivalve $\cdot$ Suspension feeding $\cdot$ Ecosystem services $\cdot$ Water clarification $\cdot$ Food depletion $\cdot$ Feeding physiology $\cdot$ Mytilus

关键词 双壳贝类 - 悬浮颗粒物滤食 - 生态系统服务 - 净水功能 食物消耗・摄食生理学・贻贝

\subsection{Introduction}

Suspension feeding, by definition, results in some degree of particle reduction in the surrounding water. This small-scale water clarification capacity of individual bivalves serves as the foundation for what is considered to be a manageable bioengineering tool for providing positive ecosystem-scale services. Dense bivalve aggregations, whether natural or introduced, can play a central role in some coastal ecosystems largely as a result of how their suspension feeding activities interact directly and indirectly with energy flow and nutrient cycling (e.g. Dame 1993, 1996; Newell 2004, chapters herein). Bivalve cultivation is widely considered to be an efficient means of nutrient removal in coastal areas affected by eutrophication as a result of the consumption of anthropogenic sources of nitrogen and phosphorous contained within phytoplankton and the sequestration of these excess nutrients into a harvestable bivalve biomass (Lindahl et al. 2005; Petersen et al. 2016). A primary symptom of eutrophication is the presence of high phytoplankton levels. The consumption of excess phytoplankton by bivalves represents a top-down control that increases water clarification and provides numerous ecological services including:

- Reduction in oxygen deficits in water and sediments by phytoplankton respiration during night, and the sedimentation of blooms that impact benthic habitat and communities through organic enrichment and microbial degradation (Newell 2004).

- Increased light penetration to the bottom, which enables recovery and expansion of sensitive sea grass and macroalgae that provide beneficial habitat for fish and invertebrates and promote increased biodiversity (Newell 2004; Petersen et al. 2016).

- Reduction in the occurrence of nuisance/toxic algal blooms (Edebo et al. 2000; Petersen 2004).

- Moderation of the infectious presence of some microbial pathogens (Pietrak et al. 2012). 
- Sequestration of biotoxins and particle-reactive contaminants through bioaccumulation in bivalves and land-based detoxification (Lindahl et al. 2005)

Nutrient extraction by bivalves represents a cumulative effect from bivalve feeding activity over the full growth cycle, and can be readily quantified from harvest data. Water clarification (i.e. particle depletion and food reduction), however, represents a transient effect on the suspended particle field in a given area that is forced by a constantly changing balance between the rates of particle removal and resupply. Large-scale food depletion by the feeding activity of bivalves has largely been predicted based on mathematical modelling in the context of estimating the production carrying capacity of bivalve aquaculture areas (e.g. Grant et al. 2008). However, this approach poses many challenges as a result of the need to accurately characterize numerous model forcing functions (Ferreira et al. 2008). These functions include spatial and temporal parameters describing the physical, morphological and physiological characteristics of the bivalve population, as well as ecological and hydrodynamic parameters describing the model domain and exchanges with the outside region. The prediction of water clarification rates (i.e. clearance rate; $\mathrm{L} \mathrm{h}^{-1}$ ) of individual bivalves is also complicated by non-linear feeding responses to multiple internal and external forcing functions (e.g. temperature, salinity, food availability and composition, energy demands, and body size) that vary over different spatial and temporal scales (Cranford et al. 2011).

Until recently, particle depletion by bivalve aggregations was "rarely studied and seldom demonstrated" (Petersen et al. 2008). High temporal and spatial variability in many of the physiological and hydrodynamic processes that control particle depletion provide a significant challenge to directly measuring particle depletion at most spatial scales. This is particularly evident at scales that would clearly indicate an ecosystem service. However, direct evidence of the magnitude and extent of suspended particulate matter depletion by bivalve populations has increased in recent years, resulting in new insights on related ecological services. Given the available literature, this review focused largely on observations of food depletion by mussel (Mytilus spp.) aquaculture activities. Suspended mussel aquaculture practices are similar to those envisaged for eutrophication remediation, except that stocking densities for the latter may be higher (Nielsen et al. 2016). Unlike aquaculture, a bioremediation farm is believed to be less constrained by the negative feedback of excessive food depletion on the productivity, meat quality and appearance of the bivalves (Petersen et al. 2016).

\subsection{Particles Captured by Suspension Feeding Bivalve Molluses}

Basic knowledge on the capacity of different species to capture different sources of marine particles is of obvious importance in determining a species ability to remove excessive quantities of those particles. Particle retention efficiency measurements, 
which are also reported as capture efficiency, provide information on the percentage of available suspended particles (numbers or concentration) that are captured as water is pumped through the mantle cavity and processed by the feeding apparatus. Retention efficiency $(R E)$ depends on particle size and the relationship has generally been described as a rapid decrease below a threshold size between 3 and $7 \mu \mathrm{m}$. All particles larger than this threshold are effectively retained (e.g. Vahl 1972; Møhlenberg and Riisgård 1978; Riisgård 1988). RE measurements depend on a number of methodological factors (e.g. body size, pumping rate, flow-through feeding chamber geometry, static chamber sampling interval, etc.) and measured $R E$ values are standardized by scaling the particle size showing maximal retention to $100 \%$ and normalising values obtained for the remaining particles to the maximal retention. Standardized $R E$ values for several bivalve species are shown in Fig. 8.1. Particle retention in $M$. edulis has been reported to rapidly decrease below approximately $4 \mu \mathrm{m}$ diameter (Fig. 8.1a) and this relationship with particle size has become firmly established in the literature. However, several field studies have reported distinctly different $R E$ size distributions. Strohmeier et al. (2012) showed that blue mussels (M. edulis) in a Norwegian fjord exhibited a seasonally variable particle retention size spectra with a more gradual increase in $R E$ from small to large particles and maximum $R E$ occurring for particle sizes between 7 and $35 \mu \mathrm{m}$. These authors suggested that these seasonal changes in $R E$ coincided with changes in the ambient particle size distribution. Cranford et al. (2016) assessed possible sources of error in $R E$ measurements using natural seston and artificial diets and confirmed that the $R E$ spectra of mussels is not always maximal for all particle sizes larger than $4 \mu \mathrm{m}$ (Fig. 8.1b). Although it is still unclear if variable particle retention is

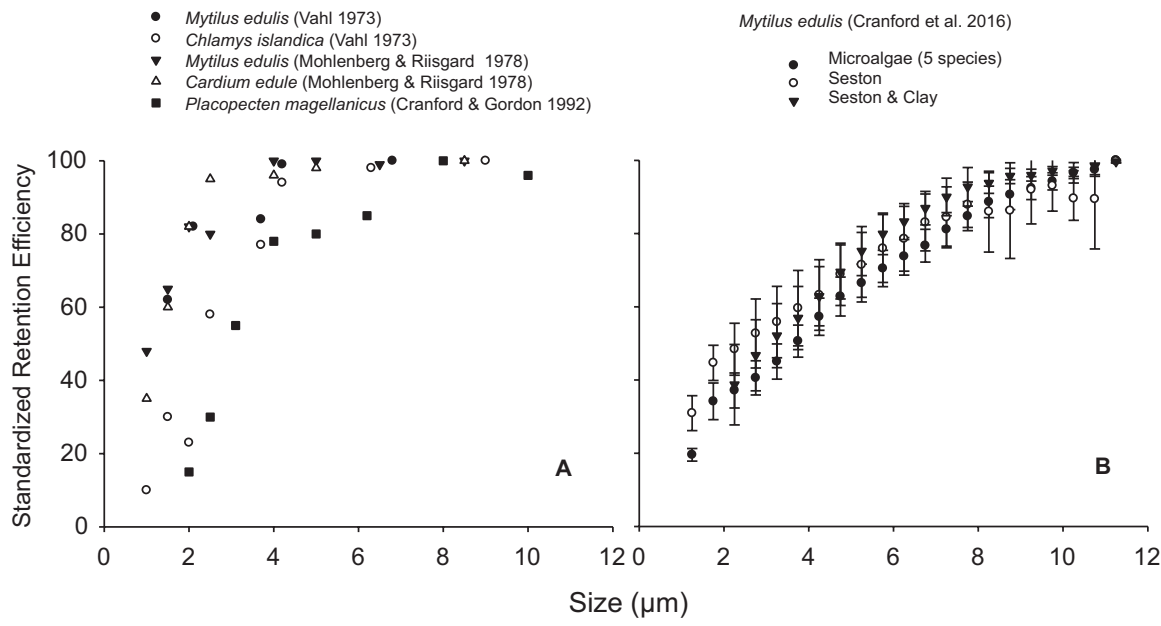

Fig. 8.1 (a) Relationship between standardized retention efficiency (\%) and particle size for the indicated suspension feeding bivalve species (redrawn from references provided). (b) Relationships for Mytilus edulis from an oligotrophic Norwegian fjord fed three diets (mean \pm SD; redrawn from data provided in Cranford et al. 2016) 
physiologically controlled or results from some exogenous factor(s) influencing the feeding mechanism, the above evidence shows that the $R E$ size spectra of bivalves does not consistently follow the traditional response shown in Fig. 8.1a (Cranford and Gordon 1992; Lucas et al. 1987; Stenton-Dozey and Brown 1992; Zhang et al. 2010; Strohmeier et al. 2012; Cranford et al. 2016).

The observations that the particle retention characteristics of some bivalve species can exhibit spatial and temporal variability has important implications for not just determining what particles are being effectively cleared from suspension by bivalves, but also for understanding how fast these particles are cleared from suspension. Cranford et al. (2016) showed that mussel clearance rates were underestimated by $25 \%$ if it was assumed that all particles larger than $4 \mu \mathrm{m}$ particles were effectively retained. Similarly, seasonal clearance rates of mussels were shown to be underestimated by an average of $26 \%(0-48 \%)$ as a result of the same erroneous assumption (Strohmeier et al. 2012). The accurate quantification of feeding rates and efficiencies represents a critical first step towards understanding the biofiltration capacity of bivalve populations and related ecosystem services.

\subsection{The Bivalve Feeding Zone}

Bivalves only directly affect particle concentrations within their feeding zone. This zone is defined here as the distance to which they can capture food and directly alter the suspended particle field through their inhalent and exhalent flows. The feeding zone has been described using a variety of modelling, laboratory and field techniques. Fluorescence-based flow visualization has been used to provide a general characterization of the dynamic characteristics of the siphon jet flows in model bivalves (e.g. Monismith et al. 1990; O'Riordan et al. 1993). Dye studies in a flume with the cockle Clinocardium nuttallii indicated that flows from the incurrent siphon entrained fluid up to $4 \mathrm{~cm}$ laterally and $2 \mathrm{~cm}$ vertically (Ertman and Jumars 1988). Concentration boundary layers can form around dense assemblages of bivalves as a result of particle capture. Muschenheim and Newell (1992) measured suspended particulate matter concentrations in the bottom $50 \mathrm{~cm}$ of the water column above a mussel bed and detected strong vertical concentration gradients that indicated an effective feeding zone of $7 \mathrm{~cm}$ distance from the seabed. Measurements of vertical gradients in particle concentrations above other mussel beds have detected a depletion gradient up to 11 and $20 \mathrm{~cm}$ from the seabed (Saurel et al. 2013 and Petersen et al. 2013, respectively). This depletion-gradient approach has also been applied to suspended mussel ropes through the use of the 'siphon mimic' technique of Petersen et al. (2008). These experiments showed depletion of phytoplankton around mussel (M. edulis) ropes in a long-line farm in a highly eutrophic Danish fjord (Nielsen et al. 2016) and in a mussel (M. galloprovincialis) raft in Spain (Petersen et al. 2008). Both studies indicated an effective feeding zone of 10 to $20 \mathrm{~cm}$, however, the average chlorophyll $a$ depletion of $27-44 \%$ in the feeding zone in the Danish 
mussel farm was considerably lower than the $63-74 \%$ reduction measured at the Spanish raft.

The magnitude of particle depletion within the feeding zone reflects a balance between the rates of particle capture by the bivalves and resupply from external waters (Fréchette et al. 1989; Muschenheim and Newell 1992; Saurel et al. 2013). The rate of particle capture by a specific bivalve species depends on a wide range of endogenous and exogenous factors (reviewed by Cranford et al. 2011). Similarly, the rate that food particles are supplied to the feeding zone is a function of multiple factors that control ecosystem productivity and multi-scale hydrological processes that include sedimentation, resuspension, advection, diffusion and mixing (Fig. 8.2). A poorly studied process that is particularly important at determining the magnitude of food depletion at the scale of the feeding zone is water re-filtration by individual and neighboring siphonate bivalves. Re-filtration is generally overlooked when scaling individual feeding rates up to entire populations despite observations that the feeding zones of multiple individuals often overlap. Bivalve species with short siphons, such as mussels, will experience the highest amount of water re-filtration (Monismith et al. 1990; O'Riordan et al. 1993). The impact of this small-scale refiltration behavior on predicting the ecosystem services of bivalves will be discussed in the following sections.

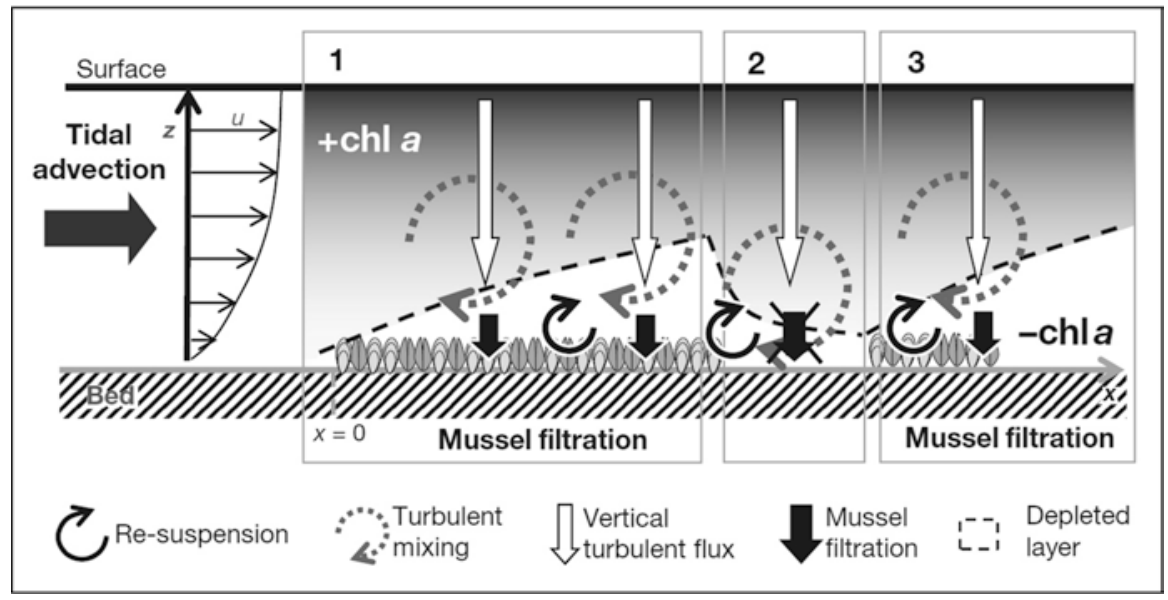

Fig. 8.2 Illustration of the particle concentration boundary layer over a mussel bed with a unidirectional flow showing some of the processes controlling the magnitude of particle depletion. The example includes a bare patch (Zone 2) in the middle of two mussel beds (Zones 1 and 3). $x$ is mussel bed length, $z$ is water depth and $u$ is current velocity (reprinted from Saurel et al. 2013) 


\subsection{Local-Scale Particle Depletion}

Given the substantial effect that dense bivalve aggregations can have on particle concentrations within their feeding zone, they may also be expected to influence the particle field at the local scale (defined here as a single bivalve aggregation or farm) through transport and mixing processes. At this scale, the potential for benthic populations to increase water column clarity and control excess phytoplankton is constrained by their spatial separation from much of the water column, vertical mixing processes and the available space for bivalves (Petersen 2004). Suspended culture operations, however, can provide bivalves with direct access to particles throughout the water column and can greatly increase bivalve biomass and biofiltration capacity per unit area relative to benthic populations. Particle depletion at the farm scale will occur if the time-scale for the stocked biomass to clear the farm volume (clearance time) is faster than the time-scale of hydrodynamic flushing (water residence time). Given the typical size of individual farms, it can be assumed that the timescale for phytoplankton growth (turnover time) is of little relevance to the replenishment of particles inside the farm compared with hydrodynamic flushing.

Concentrated arrays of mussels suspended from long-lines and rafts have been cited to cause significant levels of seston depletion for several decades (e.g. Rosenberg and Loo 1983; Rodhouse et al. 1985; Navarro et al., 1991; Fréchette et al. 1991). However, the available empirical data has yielded variable results. For example, Ogilvie et al. (2000) and Grange and Cole (1997) found significant differences between phytoplankton abundance inside and outside mussel long-line farms in Beatrix Bay, New Zealand while Murdoch and Oliver (1995) could not find any differences. Similarly, Schröder et al. (2014) detected reductions in chlorophyll $a$ levels downstream of a mussel farm, relative to upstream concentrations, but reported the opposite result for Secchi depth measurements at the same locations. Such discrepancies in the literature may be explained by differences in sampling approaches. Measuring food depletion on scales greater than the bivalve feeding zone can be problematic as temporal and spatial variability in natural food supplies in coastal regions have a tendency to mask the depletion signal (Bacher et al. 2003; Nielsen et al. 2016). Water sampling and particle sensing at discrete sampling stations may not adequately document spatial variability, and additional temporal variability can confound the interpretation of spatial data collected over the sampling period. However, in areas with low natural seston variability and a relatively high effect size (degree of particle depletion), this sampling approach has provided insights on the water clarification capacity of bivalve populations. For example, Strohmeier et al. (2005) collected chlorophyll $a$ fluorescence profiles at discrete sampling stations along the length of a long-line mussel farm and showed that more than $30 \%$ of the incoming phytoplankton biomass was depleted within the first 30-m of the farm (Fig. 8.3). Petersen et al. (2008) also measured fluorescence profiles and collected water samples for chlorophyll $a$ analysis within and around a Spanish mussel raft. These authors reported 10 to $45 \%$ reduction in phytoplankton biomass in the middle of the raft compared with reference stations. 


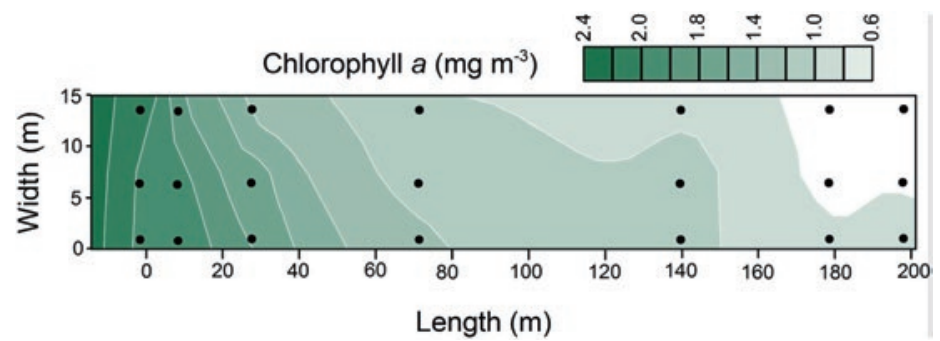

Fig. 8.3 Contour plot showing the decline in mean chlorophyll $a$ concentrations at $4 \mathrm{~m}$ depth inside a mussel long-line farm as the water flows along the length of the farm from left to right. The symbol • indicates the location of measurements. Redrawn from Strohmeier et al. (2005)

A second approach used to document local-scale particle depletion is to place electronic particle sensors (e.g. chlorophyll $a$ fluorometers and turbidity sensors) inside and outside farms for an extended period to provide information on both natural and bivalve-induced temporal variations in the suspended particle field. The disadvantage of this approach is that a large number of sensor moorings are required to provide sufficient horizontal and vertical coverage to adequately identify all sources of variations in particle concentrations and to determine the mean effect of the entire bivalve population. The size of most long-line mussel farms makes this approach impractical given that slight differences in the location of instruments can lead to contradictory results (Ogilvie et al. 2000). However, mussel rafts are considerably more compact than long-line farms and the moored sensor approach has proven effective at revealing the temporal dynamics and magnitude of seston and phytoplankton depletion inside the rafts. Cranford et al. (2014) used an array of moored in situ sensors (current speed, chlorophyll $a$ fluorescence, optical scattering and laser diffraction particle counters) to study food depletion dynamics at two mussel rafts (M. galloprovincialis) in the Ría de Betanzos, Spain. Phytoplankton (chlorophyll $a$ ) and total suspended particulate matter depletion was similar at both rafts and averaged $40 \%$ and $17 \%$, respectively. Food depletion was highest for particles in the 4-45 $\mu \mathrm{m}$ size range, which included much of the available phytoplankton, whereas the total particulate matter was dominated by larger particles that were shown to be less effectively cleared by the mussels.

A third sampling approach that has proven to be capable of quantifying both the magnitude and spatial extent of water clarification at the farm-scale is based on conducting rapid high-resolution synoptic surveys of chlorophyll $a$ and/or turbidity using in situ, airborne or satellite sensors (Gibbs 2007; Grant et al. 2007; Cranford et al. 2008; Gernex et al. 2017). This survey approach has been particularly useful for studying the water clarification capacity of long-line mussel farms as it provides spatial data over a large area in a short period. The survey data can be statistically interpolated into a map that shows the particle field inside the farm and in adjacent waters. This mapping approach essentially combines control-impact (farm vs. reference) and gradient experimental sampling designs for detecting a non-point source effect. Grant et al. (2007) and Gernex et al. (2017) employed hyperspectral remote 
sensing to show significant changes in phytoplankton concentrations within a mussel lease in eastern Canada (Tracadie Bay) and in an oyster farm in France (Bourgneuf Bay), respectively. Data from specific spectral bands were used to generate an algorithm for chlorophyll $a$ concentrations in coastal waters and these data suggest a decline in phytoplankton biomass within the farm. A more direct approach to mapping water clarification by mussels is described by Gibbs (2007) and Cranford et al. (2008) who employed vessel mounted and towed particle sensors, respectively, to rapidly survey particle concentrations within and around suspended mussel farms. Data collected in a bivalve growing area in the Marlborough Sounds with a continuous sampling pumped fluorometer showed patches of water depleted in phytoplankton (Gibbs 2007). The undulating towed-vehicle approach has the added advantage of providing particle concentration data throughout the full depth range of the mussel culture (Cranford et al. 2008; Nielsen et al. 2016). This 3-D sampling approach with a light, towed sensor vehicle has been employed at several long-line mussel culture sites in Norway (Cranford et al. 2008), The Netherlands (Cranford, unpublished data) and Denmark (Nielsen et al. 2016). Examples of phytoplankton and total particulate matter concentrations around mussel farms, obtained with this approach, are shown in Fig. 8.4.

The depth-averaged spatial distribution of suspended particle in a mussel farm shows substantial variations over time as a result of short-term fluctuations in current speed and direction and seasonal changes in the standing stock of mussels (e.g. Fig. 8.4a and b). The highest degree of food depletion often appears in the center of the farm (e.g. Fig. 8.4a and c), possibly as a result of increased water retention inside the farm or the enhanced mixing of water on the down-current side of the farm. While the concentration maps provide intuitive visual evidence of the water clarification capacity of long-line mussel farms, accurate calculations of total particle removal by the farmed mussel population requires adhering to certain methodological assumptions. Particle depletion calculations require comparison of concentrations inside and outside the farmed area, which assumes that the total surveyed area represents a single uniform water mass. This can be confirmed from contour maps of water density, which are calculated from CTD data that are also collected using the tow vehicle. For those surveys that show a plume of depleted water exiting the farmed area (e.g. Fig. 8.4b), the plume can be excluded from the reference data set. Based on this approach, Nielsen et al. (2016) provided the first direct estimates of the food depletion percentage averaged over the total farm volume. This mussel farm was specifically operated to capture and extract excess phytoplankton and nutrients from a eutrophic fjord. Particle concentrations inside the farmed volume were between 13 and 31\% lower than in the reference area around the farm. The similar spatial distribution of both chlorophyll $a$ and turbidity depletion (e.g. Fig. 8.4b) and the similar degrees of phytoplankton and total particle depletion provided a high degree of confidence in these farm-scale food depletion estimates. Although this farm has been shown to remove large quantities of excess nutrients (11-17 t N y ${ }^{-1}$ and 0.6-0.9 t $\mathrm{P} \mathrm{y}^{-1}$; Petersen et al. 2016), the mean reduction in chlorophyll $a$ concentration did not change the water quality status of the site as defined by EU and Danish Nature Agency thresholds. The farm and reference sites were both classified as "moderate" during the sampling periods (6.0 to 
A

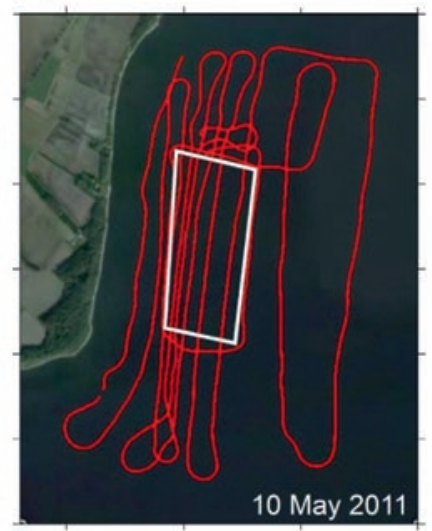

B

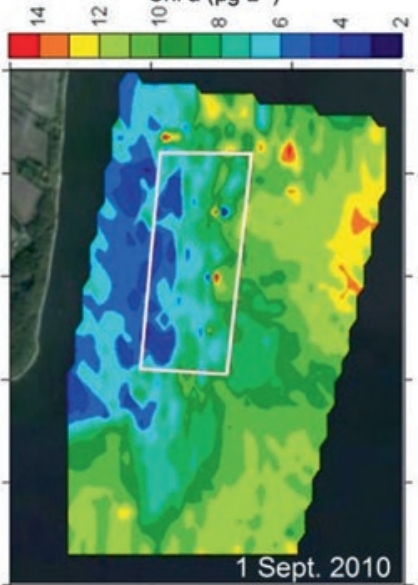

TPM ( $\left.\mathrm{mg} \mathrm{L}^{-1}\right)$

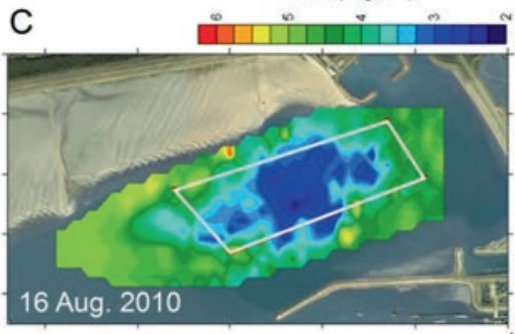

TPM (mg L $\left.{ }^{-1}\right)$
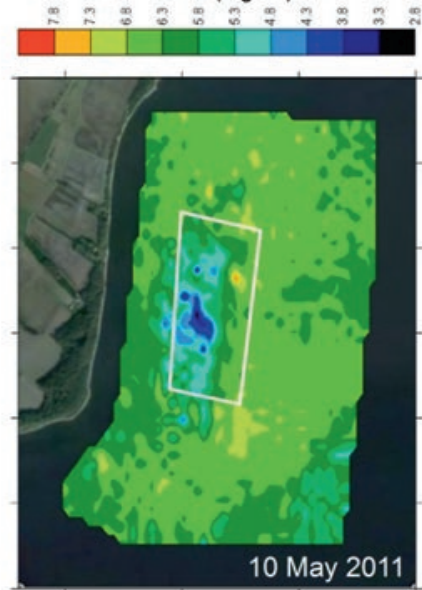

TPM ( $\left.m g L^{-1}\right)$
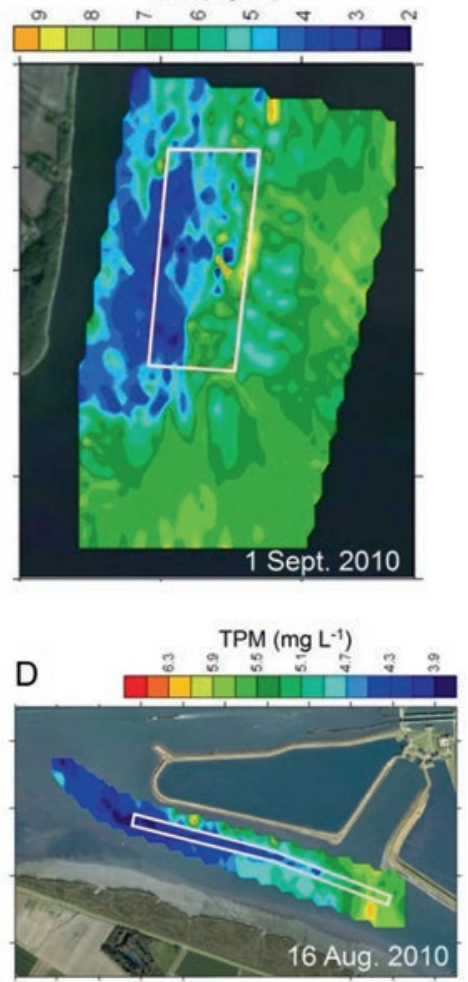

Fig. 8.4 Total particulate matter (TPM) and chlorophyll $a(\mathrm{Chl} a)$ concentrations averaged over the depth of suspended mussel farming areas (white polygon) in the Skive Fjord, Denmark (Plots $\mathbf{a}$ and $\mathbf{b}$; reprinted from Nielsen et al. 2016) and in the Oosterchelde, The Netherlands (Plots $\mathbf{c}$ and d; Cranford, unpublished data). Plot a shows both the sensor tow track (left, red line) used to construct the concentration map (right) 
$9.0 \mu \mathrm{g} \mathrm{L}{ }^{-1}$ thresholds). For the farm to reduce the status from "bad" to "moderate", chlorophyll $a$ levels would have to be consistently reduced by $33 \%$. This percentage reduction increases to $50 \%$ for changing the status from "poor" to "bad" at this site (9.0-18.0 $\mu \mathrm{g} \mathrm{L}^{-1}$ thresholds).

\subsection{Ecosystem-Scale Particle Depletion}

Many coastal regions contain dense aggregations of bivalve filter-feeders that, under certain conditions, have the potential to affect suspended particulate concentrations at the ecosystem scale. Early conclusions on the capacity of natural populations to exert bay-scale grazing control on the phytoplankton and other suspended particulate matter largely originated from relatively simple predictions of the time it takes for a known population to clear the bay volume of particles (Cloern 1982; Officer et al. 1982; Nichols 1985; Hily 1991; Smaal and Prins 1993; Dame 1996; Dame and Prins 1998; Prins et al. 1998; Newell 2004). Observations of a feedback effect on bivalve growth, presumable resulting from bivalve populations over-exploiting their food supply, provided additional early evidence of the capacity of farmed bivalves to exert large-scale control on suspended particle dynamics. Carrying capacity modelling, which is often based on estimating the food depletion potential of bivalve farms, has subsequently flourished and supported general conclusions on the topdown grazing control of phytoplankton stocks and primary production (Grant and Filgueira 2011). The direct measurement of embayment-scale particle depletion by intensive bivalve farming has only recently become possible and is described in the following case studies.

One of the most intensive bivalve growing regions in Canada is Tracadie Bay, where approximately $45 \%$ of the bay volume is leased for long-line mussel culture (Fig. 8.5). Numerous ecosystem and carrying capacity modelling exercises for this shallow coastal lagoon have indicated a large controlling effect of the mussels on the phytoplankton (e.g. Cranford et al. 2007; Grant et al. 2008). Direct evidence of the substantial phytoplankton clearance capacity of the suspended mussel culture activities in this embayment was obtained by measuring the decline in phytoplankton in the embayment over a period of time when there were no important external sources of phytoplankton entering the system. The horizontal and vertical distribution of chlorophyll $a$ in this embayment was rapidly surveyed at high resolution with a towed undulating sensor vehicle. Given the complex orientation of mussel lines in Tracadie Bay, it was not possible to completely survey the entire region in the same way as described above for individual farms. However, data obtained by resampling the same $4 \mathrm{~km}$ long tow track revealed a $29 \%$ reduction in phytoplankton concentrations in the bay (averaged across depth and distance) in a $3.75 \mathrm{~h}$ period during ebb tide (Fig. 8.5).

A second case study on the coastal-scale influence of mussel culture operations on suspended particulate matter comes from the floating raft (bateas) culture of $M$. galloprovincialis in the Galician region of Spain. This region supplies almost half of 

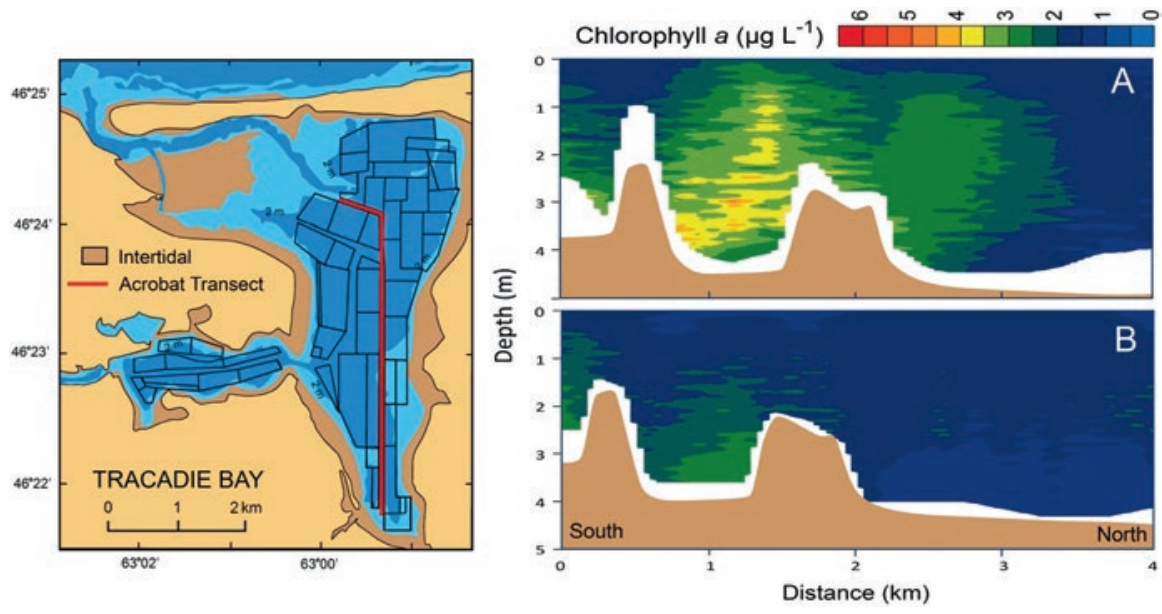

Fig. 8.5 Left: Map of Tracadie Bay showing areas leased for mussel culture and the $4 \mathrm{~km}$ tow vehicle transect (red line). Right: Chlorophyll $a$ concentrations in the water column on June 18, 2003 along the transect at (a) high tide and (b) $3.75 \mathrm{~h}$ later on ebb tide (P. Cranford, unpublished data)

the mussels produced in all the European Union and the annual production in excess of 200,000 tonnes is second only to bivalve production in China (Cranford et al. 2014). The high productivity of mussel culture in the Galician coastal region can be attributed to natural hydrographic conditions that promote nutrient fertilization and enhanced primary production in the rías. Studies on food depletion from mussel rafts in the Ría de Ares-Betanzos, Spain were conducted as part of a Canada/Spain research collaboration. This is a relatively undeveloped aquaculture area compared with other estuaries in the region and represents approximately $3 \%$ of mussel production in Galicia with a total of 147 rafts that produce approximately 10,000 tonnes of mussels annually (Labarta et al. 2004). This case study focused on a cluster of 86 rafts in a coastal embayment near Lorbé (Fig. 8.6). The towed sensor vehicle was used to survey water column properties (CTD, chlorophyll $a$ and total particulate matter) to a depth of $12 \mathrm{~m}$ in the area around the 86 rafts and in a reference area located outside the raft cluster (enclosed by dashed line in Fig. 8.6). Water column physical properties were similar in both the raft and reference areas during both surveys, indicating the presence of a single water mass throughout the survey domain.

Separate surveys conducted during ebb and flood tidal stages on 14 October, 2010 revealed lower chlorophyll $a$ and total particulate matter concentrations in the coastal embayment containing the mussel rafts than in the outside reference area (Figs. 8.6 and 8.7). This was evident in both the surface layer (1-2 m depth; Fig. 8.6) and in deeper water (4-10 m depth; Fig. 8.7). An increasing landward depletion of particulate matter was generally indicated in both surveys as the inflowing water passed successive mussel rafts. The distribution of total particulate matter showed 

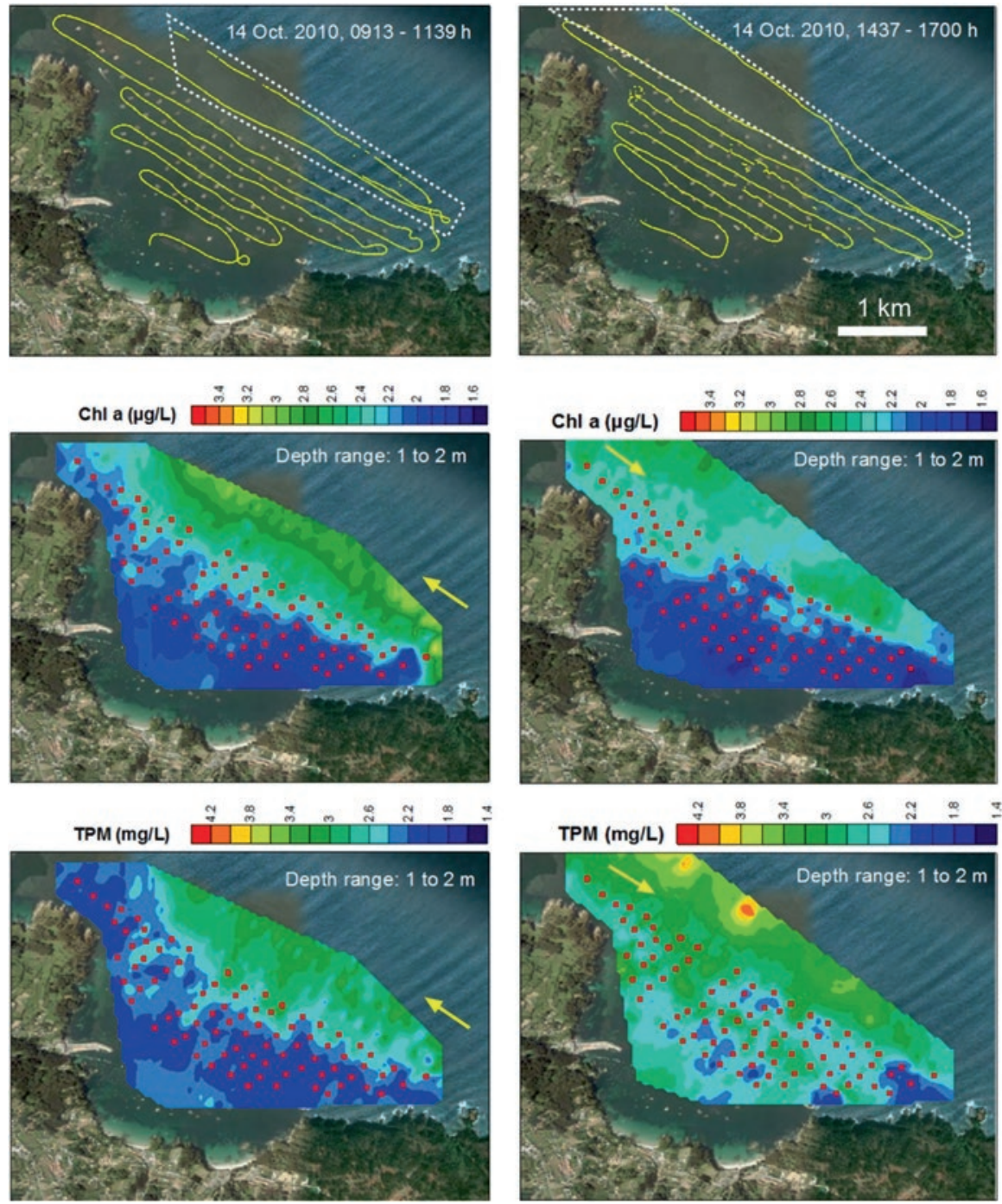

Fig. 8.6 Chlorophyll $a(\mathrm{Chl} a)$ and total particulate matter (TPM) distributions in surface water (1-2 m depth) around mussel rafts (red squares) in the Ría de Ares-Betanzos, Spain. The town of Lorbé can be seen in the lower left. The Acrobat tow tracks are shown in the upper plots along with the reference data area (dashed white polygon). The left and right plots represent ebb and flood tide conditions on 14 October 2010, respectively. The yellow arrows indicate the approximate tidal direction

greater spatial variability in the inner part of the embayment than chlorophyll $a$, perhaps as a result of land runoff, and/or the resuspension of sediments by wave action near the coastline. Consequently, the spatial distribution of chlorophyll $a$ provided the most accurate indication of the water clarification capacity of the 

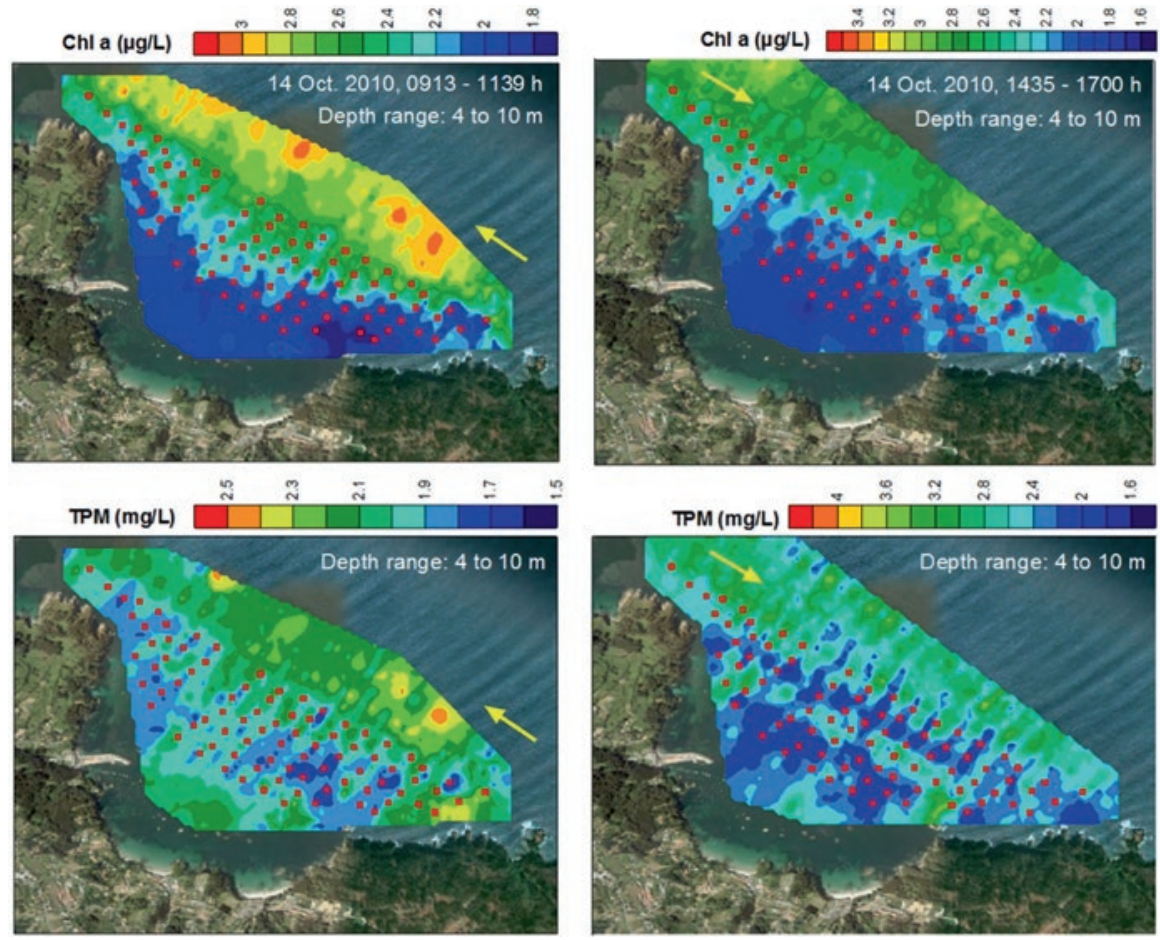

Fig. 8.7 Same as Fig. 8.6 except that the particle concentration data are from the 4 to $10 \mathrm{~m}$ depth range and the tow tracks (same as Fig. 8.6) are not shown

Table 8.1 Average $( \pm 1 \mathrm{SD})$ chlorophyll $a(\mathrm{Chl} a)$ and total particulate matter (TPM) concentrations in the reference and remaining (mussel rafts) sections of the sensor tow path shown in Fig. 8.7. The average percentage reduction of each particle type was calculated for different depth zones and tidal phases

\begin{tabular}{|c|c|c|c|c|c|c|}
\hline \multirow[b]{2}{*}{ Data set } & \multicolumn{2}{|l|}{ Reference area } & \multicolumn{2}{|l|}{ Raft area } & \multicolumn{2}{|c|}{$\begin{array}{l}\text { Percentage } \\
\text { reduction }\end{array}$} \\
\hline & Chl $a\left(\mu \mathrm{g} \mathrm{L}^{-1}\right)$ & $\mathrm{TPM}\left(\mathrm{mg} \mathrm{L}^{-1}\right)$ & Chl $a\left(\mu \mathrm{g} \mathrm{L}^{-1}\right)$ & TPM $\left(\mathrm{mg} \mathrm{L}^{-1}\right)$ & Chl $a$ & TPM \\
\hline \multicolumn{7}{|l|}{ Ebb tide } \\
\hline $1-2 \mathrm{~m}$ & $2.69(0.21)$ & $2.72(0.36)$ & $2.10(0.18)$ & $2.27(0.19)$ & 22.0 & 16.4 \\
\hline $4-10 \mathrm{~m}$ & $2.67(0.26)$ & $2.05(0.19)$ & $2.29(0.31)$ & $1.93(0.18)$ & 14.0 & 5.7 \\
\hline \multicolumn{7}{|c|}{ Flood tide } \\
\hline $1-2 \mathrm{~m}$ & $2.38(0.17)$ & $3.11(0.34)$ & $2.00(0.37)$ & $2.66(0.37)$ & 16.0 & 14.3 \\
\hline $4-10 \mathrm{~m}$ & $2.70(0.30)$ & $2.56(0.45)$ & $2.12(0.23)$ & $2.23(0.38)$ & 21.5 & 12.8 \\
\hline
\end{tabular}

mussel rafts. Table 8.1 provides summary data on average concentration values in the reference and raft regions and the overall percentage reduction of particles by the cultured mussels. Although some areas of this embayment exhibited ca. $40 \%$ lower chlorophyll $a$ concentrations than measured in the reference area (Figs. 8.6 and 8.7), average chlorophyll $a$ levels in the raft region were between 14 and $22 \%$ 
lower than measured in the outside area (Table 8.1). The high flux of particles into the raft area, facilitated by both high phytoplankton concentrations in the Ría de Ares-Betanzos and rapid tidal flushing, prevents higher levels of food depletion and facilitates the high growth rates and productivity of mussels in this, and other, Galician rías.

\subsection{Self-Limitation of Water Clarification Capacity}

The increasing availability of empirically derived parameters controlling the particle depletion capacity of bivalve farms is helping to increase certainty in model predictions. Measurements of particle depletion inside mussel rafts (M. galloprovincialis) in the Ría de Betanzos showed that phytoplankton depletion varied substantially over a tidal cycle, largely as a result of tidal variations in current speed (Cranford et al. 2014). These authors developed a raft-scale food depletion model that provided average values that were within 5 and $11 \%$ of the measured phytoplankton depletion for the two rafts. However, this level of accuracy was only achieved after accounting for the effect of raft-induced flow reduction on water refiltration by the cultured mussels. The capacity of raft structures, including the mussels themselves, to slow the incoming current speed to the extent that the mussels begin to significantly re-filter water at certain tidal stages was shown to represent an important self-limitation on the maximum degree of food depletion. The raft model consistently overestimated the observed food depletion without considering this constraint. Bivalve clearance rate measurements are conducted in a manner that intentionally excludes any possibility of water re-filtration. However, re-filtration does occur in nature and results in a reduction in particle capture rate (filtration rate) even though clearance rate remains constant. The model correction required to account for water re-filtration will depend on local stocking densities, but the raft study indicated a linear decrease in the 'realized' clearance rate as current velocities fall below $2 \mathrm{~cm} \mathrm{~s}^{-1}$ (Cranford et al. 2014). Inclusion of a re-filtration function in the raft model resulted in particle depletion within the raft area being restricted to below a maximum of $56 \%$.

Model development was also conducted in combination with direct measurements of food depletion at the commercial-scale nutrient extractive mussel farm in the highly eutrophic Skive Fjord, Denmark (Nielsen et al. 2016). As noted above, particle concentrations inside this 18.8 ha farm were between 13 and $31 \%$ lower than in the reference areas around the farm (Figs. 8.4a and b). The food depletion model was developed for this farm to estimate the optimal mussel density required to maximize removal of excess phytoplankton. Rather than using the conventional approach of parameterizing the model with experimental mussel clearance rates from the literature, realized clearance rates were calculated from the measured food depletion, current velocity and mussel density. These realized clearance rates were 40-74\% lower than typical experimental values. Nielsen et al. (2016) suggested that this was the result of a high degree of water re-filtration during passage through this 
farm. Flow conditions in the Skive Fjord are primarily driven by fresh water runoff and the current speeds inside the farm averaged just $2.7 \mathrm{~cm} \mathrm{~s}^{-1}$ during the two periods when farm-scale food depletion was measured. At these low flows, the high stocking density of mussels (300-600 mussels $\mathrm{m}^{-3}$ ) will re-filter a large fraction of the water entering their feeding zone. Water re-filtration by mussels results in particle capture rates being considerably lower than expected based on the rate of water processing by the feeding apparatus (i.e. experimental clearance rate). This reduction in particle filtration rate, combined with the relatively low rate of transport of particles to the feeding zone (i.e. low current speed) likely contributed to the relatively low food depletion percentage at this site (averaged 22\%; Nielsen et al. 2016) compared with the Spanish rafts (averaged 40\%; Cranford et al. 2014). The raft sites were stocked at a density of approximately 300 mussels $\mathrm{m}^{-3}$. Although somewhat counter intuitive, the higher depletion at the raft site can be explained by the higher current speeds replenishing water in the feeding zone and thereby enabling the full capacity of the mussel to capture particles.

\subsection{Ecosystem-Based Assessment of Biofiltration Services}

Positive ecological benefits from the water clarification capacity of dense bivalve aggregations, whether predicted or observed, should not be assumed without first undertaking a detailed assessment of a wide range of potential ecosystem responses. Evidence of negative effects from the biofiltration activities of bivalves have largely been consigned to a few intensively cultured areas in shallow, poorly flushed waters; where the biodeposition of undigested organic matter in bivalve faeces can affect sediment geochemistry and benthic infaunal communities (e.g. Cranford et al. 2009; Hargrave et al. 2008; Burkholder and Shumway 2011). However, to ensure that human activities are carried out in a sustainable manner, an ecosystem-based and knowledge-based approach is essential for environmental management decision making. Consequently, some additional pathways of effect are considered in the following discussion to promote an objective assessment of the net ecological services provided by intensive bivalve grazing activities.

The reduced turbidity and increased light penetration to the bottom from bivalve grazing is expected to have a positive effect by extending the depth range of benthic macrophytes and microphytobenthos (Newell 2004; Newell and Koch 2004). Deslous-Paoli et al. (1998) reviewed studies on macrophyte distributions during the development of extensive oyster and mussel culture operations in the Thau Lagoon, France. They concluded that Zostera spp. extended its distribution from shallow regions to areas up to $5 \mathrm{~m}$ deep. However, De Casabianca et al. (1997) noted a shift from the dominance of Zostera in this same lagoon to communities composed of opportunistic algae (Ulva and Gracilaria spp.). Macrophytes also tend to be absent under extensive aquaculture structures as a result of shading (Deslous-Paoli et al. 1998). Although increased light penetration may be expected to permit an increase in microphytobenthos growth, this process may promote nitrogen retention in the 
system as opposed to the desired removal of nitrogen through denitrification by the sediment microbial community (Newell 2004). Similarly, the mussels can direct substantially more nitrogen to sediments in their biodeposits than is removed in the harvest, resulting in increased nitrogen retention and recycling in the coastal zone (Cranford et al. 2007). Consequently, the desired ecosystem service of bivalve stocks to promote excess nitrogen removal through water clarification may not be achieved under some conditions.

The numerous studies in the Oosterschelde estuary (The Netherlands), as described in Smaal et al. (2013), collectively provide a case study on some additional large-scale ecological interactions associated with the biofiltration activities of cultured mussels. Nutrient concentrations in this estuary are generally low but primary production is nutrient limited only for short periods because of the regulating role of bivalves. Bivalve grazing and their effects on nutrient regeneration initially stimulated primary production and phytoplankton turnover. However, the total filtration capacity of bivalves stocks in the estuary increased by $30 \%$ between 1995 and 2009, and a point was reached where grazing pressure controlled primary production (Smaal et al. 2013). The resulting switch from bottom-up to top-down (grazing) control of the phytoplankton was cited as the most likely cause for the observed $49 \%$ decline in primary production in the basin and possibly contributed to a $38 \%$ decrease in the annual growth of wild commercial cockles.

Ecosystem-scale phytoplankton depletion by bivalves may be expected to be accompanied by a shift in phytoplankton composition towards small algal cells. Bivalves do not effectively capture small nanoplankton and all types of picoplankton (photoautotrophic and heterotrophic). Picophytoplankton may be expected to thrive under high bivalve grazing pressure because the pelagic nano-protists that feed on their populations are also a trophic resource for bivalves (Dupuy et al. 1999; Maar et al. 2007; Nielsen and Maar 2007; Trottet et al. 2008). The rapid nutrient uptake and growth rates of small cells (Stockner 1988) can also be enhanced by bivalve-mediated effects on light penetration and nutrient regeneration. Enclosure experiments in which $M$. edulis were sufficiently abundant to deplete nano- and microphytoplankton, showed that the picoplankton became dominant (Riemann et al. 1988; Olsson et al. 1992; Granéli et al. 1993). Size-selective bivalve grazing has resulted in high abundance of picophytoplankton in the Thau Lagoon, France (Courties et al. 1994; Vaquer et al. 1996; Dupuy et al., 2000; Souchu et al. 2001), in land-locked Norwegian oyster ponds (Klaveness 1990), and in several other estuaries in Canada, Itay, and The Netherlands (Cranford et al. 2008; Caroppo 2000; Smaal et al. 2013). A shift towards small algal cells over a scale of $20 \mathrm{~km}$ was observed to accompany the significant depletion of phytoplankton in water passing a large natural mussel bed in the turbulent Öresund strait (Norén et al. 1999). These results largely confirm the hypothesis that intense bivalve grazing gives small phytoplankton a competitive advantage such that they dominate under conditions where bivalves exert significant control over the larger phytoplankton. The ecosystem consequences of such an alteration to the base of the food chain are largely unknown.

A weight of evidence exists to conclude that extensive bivalve aquaculture activities in several coastal areas may alter ecosystem structure and function as a result of 
their grazing influence on low-trophic level resources; including the phytoplankton, pelagic ciliates and flagellates, zooplankton, and detritus. A general conclusion from ecosystem modelling is that bivalve aquaculture routes energy flow towards benthic food webs instead of the pelagic (e.g. Dame 1996; Cranford et al. 2007; Filgueira and Grant 2009). Ecosystem-scale control of the phytoplankton and other pelagic trophic resources by suspended bivalves would represent a significant trophic interaction that may upset critical ecological equilibria, possibly resulting in cascading food web changes. Gibbs (2007) noted that several possible consequences can result from the ecosystem effects of intensive bivalve grazing; (1) reducing/ replacing the role of zooplankton, (2) shifting benthic communities from filter- to deposit-feeders, and (3) redirecting energy flow and nutrient cycling in the microbial loop. Bivalve culture competes with the ecological role of mesozooplankton and may, under certain conditions, replace that role (Jiang and Gibbs 2005; Gibbs 2007). The transfer of energy up to other trophic levels through the consumption of bivalves by predators is considerably weaker than the transfer of energy through zooplankton. The magnitude of ecological services associated with bivalve grazing are always site-specific with the net result depending on multiple ecosystem processes. Positive effects of bivalve grazing are likely to occur in areas where bivalve populations serve as a manageable biofilter that improves water quality and lessens coastal eutrophication (e.g. Lindahl 2011). However, it is important to be mindful of the potential for less desirable ecosystem interactions that may be associated with intensive and extensive suspended bivalve aquaculture activities.

\subsection{Conclusions}

Studies in bivalve ecology have emphasized that phytoplankton dynamics in coastal regions may be strongly coupled with bivalve filter-feeding activity to the extent that the bivalve community plays a major ecological role in controlling phytoplankton biomass and trophic structure. Suspended culture operations provide the greatest potential for maximizing the water clarification services of bivalve filter-feeders owing to the direct access of dense populations to particulate matter throughout the water column. Direct measurements of the water clarification capacity of mussel farms have revealed up to $80 \%$ particle depletion inside some sections of the farm. When averaged across the total farm volume, some the most intensive suspended mussel aquaculture operations currently in production have been observed to reduce suspended particle concentrations by $13-31 \%$. The spatial extent and magnitude of this control on the phytoplankton is always site- and time-specific as a result of factors controlling food consumption (e.g. intensity of culture, food availability and composition, and temperature) and food resupply processes such as tidal flushing and primary production. Coastal ecosystems are often highly productive and dynamic and exhibit a large facility to replenish bivalve-mediated food depletion through hydrological processes. Bivalve feeding can also exert a positive feedback on primary production (Dame 1996). Progressively increasing the standing stock of 
bivalves to achieve greater water clarification benefits will eventually lead to inefficiencies in bivalve feeding related to increased flow reduction from structure drag, which facilitates an increase in water re-filtration. These physical and biological processes ultimately constrain the maximum water clarification capacity of the population. Nutrient extraction in the bivalve harvest represents one of the most promising measures for controlling the consequences of anthropogenic nutrient supply to coastal waters (Petersen et al. 2016). Attempts to also maximize the ecological services from water clarification should consider possible interactions with nutrient extraction. This aligns with the concept of production carrying capacity in which aquaculture farm production (i.e. nutrient extraction) is maximized by preventing excessive food depletion (water clarification).

Acknowledgements The contributions of the many individuals that facilitated and participated in the synoptic surveys of food depletion at mussel aquaculture farms summarized in this review are gratefully recognized. Surveys conducted in Norway were orchestrated by Øivind Strand and Tore Strohmeier through funding by the Research Council of Norway. The work in Denmark were conducted as part of the Mussels-Mitigation and Feed for Husbandry (MuMiHus) project led by Jens Petersen and funded by the Danish Council for Strategic Research. Phytoplankton depletion studies in Spain were conducted under a Canadian-Spanish joint research project (Ecological Sustainability of Suspended Mussel Aquaculture-ESSMA) with assistance from Maria José Fernández-Reiriz and Uxio Labarta and funding from Fisheries and Oceans Canada. Studies in The Netherlands were assisted by Pauline Kamermans and Karin Troost as part of a project funded by the Dutch Ministry of Economic Affairs. Dr. Ingvar Olsen and dr Fred Jean are acknowledged for their review on the manuscript.

\section{References}

Bacher C, Grant J, Hawkins AJS, Fang J, Zhu M, Besnard M (2003) Modelling the effect of food depletion on scallop growth in Sungo Bay (China). Aquat Living Resour 16:10-24

Burkholder JM, Shumway SE (2011) Bivalve shellfish aquaculture and eutrophication. In: Shumway SE (ed) Shellfish aquaculture and the environment. Wiley-Blackwell, Hoboken

Caroppo C (2000) The contribution of picophytoplankton to community structure in a Mediterranean brackish environment. J Plankton Res 22:387-397

Cloern JE (1982) Does the benthos control phytoplankton biomass in South San Francisco Bay? Mar Ecol Prog Ser 9:191-202

Courties C, Vaquer A, Lautier J, Troussellier M, Chrétiennot-Dinet MJ, Neveux J, Machado C, Claustre H (1994) Smallest eukaryotic organism. Nature 370:255

Cranford PJ, Gordon DC (1992) The influence of dilute clay suspensions on sea scallop (Placopecten magellanicus) feeding-activity and tissue-growth. Neth J Sea Res 30:107-120

Cranford PJ, Strain PM, Dowd M, Hargrave BT, Grant J, Archambault MC (2007) Influence of mussel aquaculture on nitrogen dynamics in a nutrient enriched coastal embayment. Mar Ecol Prog Ser 347:61-78

Cranford PJ, Li W, Strand Ø, Strohmeier T (2008) Phytoplankton depletion by mussel aquaculture: high resolution mapping, ecosystem modeling and potential indicators of ecological carrying capacity. ICES CM 2008/H:12:1-5

Cranford PJ, Hargrave BT, Doucette L (2009) Benthic organic enrichment from suspended mussel (Mytilus edulis) culture in Prince Edward Island, Canada. Aquaculture 292:189-196 
Cranford PJ, Ward JE, Shumway SE (2011) Bivalve filter feeding: variability and limits of the aquaculture biofilter. In: Shumway SE (ed) Shellfish aquaculture and the environment. WileyBlackwell, Hoboken

Cranford PJ, Duarte P, Robinson SMC, Fernández-Reiriz FJ, Labarta U (2014) Suspended particulate matter depletion and flow modification inside mussel (Mytilus galloprovincialis) culture rafts in the Ría de Betanzos. Spain J Exp Mar Biol Ecol 452:70-81

Cranford PJ, Strohmeier T, Filgueira R, Strand Ø (2016) Potential methodological influences on the determination of particle retention efficiency by suspension feeders: Mytilus edulis and Ciona intestinalis. Aquat Biol 25:61-73

Dame RF (1993) Bivalve filter feeders in estuarine and coastal ecosystem processes. Springer, New York

Dame RF (1996) Ecology of marine bivalves. An ecosystem approach. CRC Press, Boca Raton

Dame RF, Prins TC (1998) Bivalve carrying capacity in coastal ecosystems. Aquat Ecol 31:409-421

De Casabianca T, Laugier T, Collart D (1997) Impact of shellfish farming eutrophication on benthic macrophyte communities in the Thau lagoon, France. Aquacult Int 5:301-314

Deslous-Paoli JM, Souchu P, Mazouni N, Juge C, Dagault F (1998) Relations milieu-ressources: impact de la conchyliculture sur un environnement launaire mediterraneen (Thau). Oceanol Acta 21:831-843

Dupuy C, Le Gall S, Hartmann HJ, Bréret M (1999) Retention of ciliates and flagellates by the oyster Crassostrea gigas in French Atlantic coastal ponds: protists as a trophic link between bacterioplankton and benthic suspension-feeders. Mar Ecol Prog Ser 177:165-175

Dupuy C, Vaquer A, Lam HT, Rougier C, Mazouni N, Lautier J, Collos Y, Le Gall S (2000) Feeding rate of the oyster Crassostrea gigas in a natural planktonic community of the Mediterranean Thau Lagoon. Mar Ecol Prog Ser 205:171-184

Edebo L, Haamer J, Lindahl O, Loo LO, Piriz L (2000) Recycling of macronutrients from sea to land using mussel cultivation. Int J Environ Pollut 13:190-207

Ertman SC, Jumars PA (1988) Effects of bivalve siphonal currents on the settlement of inert particles and larvae. J Mar Res 46:797-813

Ferreira JG, Hawkins AJS, Monteiro P, Moore H, Service M, Pascoe PL, Ramos L, Sequeira A (2008) Integrated assessment of ecosystem-scale carrying capacity in shellfish growing areas. Aquaculture 275:138-151

Filgueira R, Grant J (2009) A box model for ecosystem-level management of mussel carrying capacity in a coastal bay. Ecosystems 12:1222-1233

Fréchette M, Butman CA, Geyer WR (1989) The importance of boundary-layer flows in supplying phytoplankton to the benthic suspension feeder, Mytilus edulis L. Limnol Oceanogr 34:19-36

Fréchette M, Booth DA, Myrand B, Bermard H (1991) Variability and transport of organic seston near a mussel aquaculture site. ICES Mar Sci Symp 192:24-32

Gernex P, Doxaran D, Barillé L (2017) Shellfish aquaculture from space: potential of Sentinel2 to monitor tide-driven changes in turbidity, chlorophyll concentration and oyster physilogical response at the scale of an oyster farm. Front Mar Sci 4:1-15

Gibbs MT (2007) Sustainability performance indicators for suspended bivalve aquaculture activities. Ecol Indic 7:94-107

Granéli E, Olsson P, Carlsson P, Graneli W, Nylander C (1993) Weak 'top-down' control of dinoflagellate growth in the coastal Skagerrak. J Plankton Res 15:213-237

Grange K, Cole R (1997) Mussel farming impacts. Aquaculture Update 19:1-3

Grant J, Filgueira R (2011) The application of dynamic modeling to prediction of production carrying capacity in shellfish farming. In: Shumway SE (ed) Shellfish aquaculture and the environment. Wiley-Blackwell, Hoboken

Grant J, Bugden G, Horne E, Archambault M-C, Carreau M (2007) Remote sensing of particle depletion by coastal suspension-feeders. Can J Fish Aquat Sci 64:387-390

Grant J, Bacher C, Cranford PJ, Guyondet T, Carreau M (2008) A spatially explicit ecosystem model of seston depletion in dense mussel culture. J Mar Systems 73:155-168

Hargrave BT, Doucette LI, Cranford PJ, Milligan TG (2008) Influence of mussel aquaculture on sediment organic enrichment in a nutrient-rich coastal embayment. Mar Ecol Prog Ser 365:137-149 
Hily C (1991) Is the activity of benthic suspension feeders a factor controlling water quality in the Bay of Brest? Mar Ecol Prog Ser 69:179-188

Jiang W, Gibbs MT (2005) Predicting the carrying capacity of bivalve shellfish culture using a steady, linear food web model. Aquaculture 244:171-185

Klaveness D (1990) Size structure and potential food value of the plankton community to Ostrea edulis L. in a traditional Norwegian Østerspoil. Aquaculture 86:231-247

Labarta U, Fernández Reiriz MJ, Pérez Camacho A, Pérez Corbacho E (2004) Bateeiros, Mar, mejillón. Una perspectiva bioeconómica (Serie Estudios Sectoriales). Fundación Caixa Galicia. A Coruña, España

Lindahl O (2011) Mussel farming as a tool for re-eutrophication of coastal waters: experiences from Sweden. In: Shumway SE (ed) Shellfish aquaculture and the environment. WileyBlackwell, Hoboken

Lindahl O, Hart R, Hernroth B, Kollberg S, Loo LO, Olrog L, Rehnstam-Holm A, Svensson J, Svensson S, Syversen U (2005) Improving marine water quality by mussel farming: a profitable solution for Swedish society. Ambio 34:131-138

Lucas MI, Newell RC, Shumway SE, Seiderer LJ, Bally R (1987) Particle clearance and yield in relation to bacterioplankton and suspended particulate availability in estuarine and open coast populations of the mussel Mytilus edulis. Mar Ecol Prog Ser 36:215-224

Maar M, Nielsen TG, Bolding K, Burchard H, Visser AW (2007) Grazing effects of blue mussel Mytilus edulis on the pelagic food web under different turbulence conditions. Mar Ecol Prog Ser 339:199-213

Møhlenberg F, Riisgård HU (1978) Efficiency of particle retention in 13 species of suspension feeding bivalves. Ophelia 17:239-246

Monismith SG, Koseff JR, Thompson JK, O'Riordan KA, Nepf HM (1990) A study of model bivalve siphonal currents. Limnol Oceanogr 35:680-696

Murdoch R, Oliver M (1995) Study of chlorophyll concentrations within and around mussel farms: Beatrix Bay, Pelorus Sound. 1995r6-WN, National Institute of Water and Atmospheric Research, Wellington

Muschenheim D, Newell C (1992) Utilization of seston flux over a mussel bed. Mar Ecol Prog Ser 85:131-136

Navarro E, Iglesias J, Perez-Camacho A, Labarta U, Beiras R (1991) The physiological energetics of mussels (Mytilus galloprovincialis L) from different cultivation rafts in the Ria de Arosa (Galicia, NW Spain). Aquaculture 94:197-212

Newell RIE (2004) Ecosystem influences of natural and cultivated populations of suspensionfeeding bivalve molluscs: a review. J Shellfish Res 23:51-61

Newell RIE, Koch EW (2004) Modeling seagrass density and distribution in response to changes in turbidity stemming from bivalve filtration and seagrass sediment stabilization. Estuaries 27:793-806

Nichol FH (1985) Increased benthic grazing: an alternative explanation for low phytoplankton biomass in northern San Francisco Bay during the 1976-1977 drought. Est Coast Shelf Sci 21:379-388

Nielsen TG, Maar M (2007) Effects of a blue mussel Mytilus edulis bed on vertical distribution and composition of the pelagic food web. Mar Ecol Prog Ser 339:185-198

Nielsen P, Cranford PJ, Maar M, Petersen JK (2016) Magnitude, spatial scale and optimization of ecosystem services from a nutrient extraction mussel farm in the eutrophic Skive Fjord, Denmark. Aqua Env Int 8:311-329

Norèn F, Haamer J, Lindahl O (1999) Changes in the plankton community passing a Mytilus edulis mussel bed. Mar Ecol Prog Ser 191:87-194

O'Riordan CA, Monismith SG, Koseff JR (1993) A study of concentration boundary-layer formation over a bed of model bivalves. Limnol Oceanogr 38:1712-1729

Officer CB, Smayda TJ, Mann R (1982) Benthic filter feeding: a natural eutrophication control. Mar Eco Prog Ser 9:203-210

Ogilvie SC, Ross AH, Schiel DR (2000) Phytoplankton biomass associated with mussel farms in Beatrix Bay, New Zealand. Aquaculture 181:71-80 
Olsson P, Graneli E, Carlsson P, Abreu P (1992) Structure of a post spring phytoplankton community by manipulation of trophic interactions. J Exp Mar Biol Ecol 158:249-266

Petersen JK (2004) Grazing on pelagic primary producers - the role of benthic suspension feeders in estuaries. In: Nielsen SL, Banta G, Pedersen MF (eds) Estuarine nutrient cycling: the influence of primary producers. Kluwer Academic, Dordrecht, pp 129-152

Petersen JK, Nielsen TG, van Duren L, Maar M (2008) Depletion of plankton in a raft culture of Mytilus galloprovincialis in Ria de Vigo, NW Spain. I. Phytoplankton. Aquat Biol 4:113-125

Petersen JK, Maar M, Ysebaert T, Herman P (2013) Near-bed gradients in particles and nutrients above a mussel bed in the Limfjorden: influence of physical mixing and mussel filtration. Mar Ecol Prog Ser 490:137-146

Petersen JK, Saurel C, Nielsen P, Timmermann K (2016) The use of shellfish for eutrophication control. Aquac Int 24:857-878

Pietrak MR, Molly SD, Bouchard DA, Singer JT, Bricknell I (2012) Potential role of Mytilus edulis in modulating the infectious pressure of Vibrio anguillarum $02 \beta$ on an integrated multi-trophic aquaculture farm. Aquaculture 326-329:36-39

Prins TC, Smaal AC, Dame RF (1998) A review of the feedbacks between bivalve grazing and ecosystem processes. Aquat Ecol 31:349-359

Riemann B, Nielsen TG, Horsted SJ, Bjernsen PK, Pock-Steen J (1988) Regulation of phytoplankton biomass in estuarine enclosures. Mar Ecol Prog Ser 48:205-215

Riisgård HU (1988) Efficiency of particle retention and filtration-rate in 6 species of northeast American bivalves. Mar Ecol Prog Ser 45:217-223

Rodhouse PG, Roden CM, Hensey MP, Ryan TH (1985) Production of mussels, Mytilus edulis, in suspended culture and estimates of carbon and nitrogen flow: Killary Harbour, Ireland. J Mar Biol Ass UK 65:55-68

Rosenberg R, Loo L-O (1983) Energy flow in a Mytilus edulis culture in western Sweden. Aquaculture 53:151-161

Saurel C, Petersen JK, Wiles P, Kaiser MJ (2013) Turbulent mixing limits mussel feeding: direct estimates of feeding rate and vertical diffusivity. Mar Ecol Prog Ser 485:105-121

Schröder T, Stank J, Schernewski G, Krost P (2014) The impact of a mussel farm on water transparency in the Kiel Fjord. Ocean Coast Manag 101:42-52

Smaal AC, Prins TC (1993) The uptake of organic matter and the release of inorganic nutrients by suspension feeding bivalve beds. In: Dame RF (ed) Bivalve filter feeders in estuarine and coastal ecosystem processes. Springer, Heidelberg, pp 273-298

Smaal AC, Schellekens T, van Stralen MR, Kromkamp JC (2013) Decrease of the carrying capacity of the Oosterschelde estuary (SW Delta, NL) for bivalve filter feeders due to overgrazing? Aquaculture 404-405:28-34

Souchu P, Vaquer A, Collos Y, Landrein S, Deslous-Paoli J-M, Bibent B (2001) Influence of shellfish farming activities on the biogeochemical composition of the water column in Thau lagoon. Mar Ecol Prog Ser 218:141-152

Stenton-Dozey JME, Brown AC (1992) Clearance and retention efficiency of natural suspended particles by the rock-pool bivalve Venerupis corrugatus in relation to tidal availability. Mar Ecol Prog Ser 82:175-186

Stockner JG (1988) Phototrophic picoplankton: and overview from marine and freshwater ecosystems. Limnol Oceanogr 33:765-775

Strohmeier T, Aure J, Duinker A, Castberg T, Svardal A, Strand Ø (2005) Flow reduction, seston depletion, meat content and distribution of diarrhetic shellfish toxins in a long-line blue mussel (Mytilus edulis) farm. J Shellfish Res 24:15-23

Strohmeier T, Strand Ø, Alunno-Bruscia M, Duinker A, Cranford PJ (2012) Variability in particle retention efficiency by the mussel Mytilus edulis. J Exp Mar Biol Ecol 412:96-102

Trottet A, Roy S, Tamigneaux E, Lovejoy C, Tremblay R (2008) Impact of suspended mussels (Mytilus edulis L.) on plankton communities in a Magdalen islands lagoon (Québec, Canada): A mesocosm approach. J Exp Mar Biol Ecol 365:103-115 
Vahl O (1972) Efficiency of particle retention in Mytilus edulis L. Ophelia 10:17-25

Vaquer A, Troussellier M, Courties C, Bibent B (1996) Standing stock and dynamics of picophytoplankton in the Thau Lagoon (Northwest Mediterranean Coast). Limnol Oceanogr 41:1821-1828

Zhang JH, Fang JG, Liang XM (2010) Variations in retenti on efficiency of bivalves to different concentrations and organic content of suspended particles. Chin J Oceanol Limnol 28:10-17

Open Access This chapter is licensed under the terms of the Creative Commons Attribution 4.0 International License (http://creativecommons.org/licenses/by/4.0/), which permits use, sharing, adaptation, distribution and reproduction in any medium or format, as long as you give appropriate credit to the original author(s) and the source, provide a link to the Creative Commons license and indicate if changes were made.

The images or other third party material in this chapter are included in the chapter's Creative Commons license, unless indicated otherwise in a credit line to the material. If material is not included in the chapter's Creative Commons license and your intended use is not permitted by statutory regulation or exceeds the permitted use, you will need to obtain permission directly from the copyright holder. 